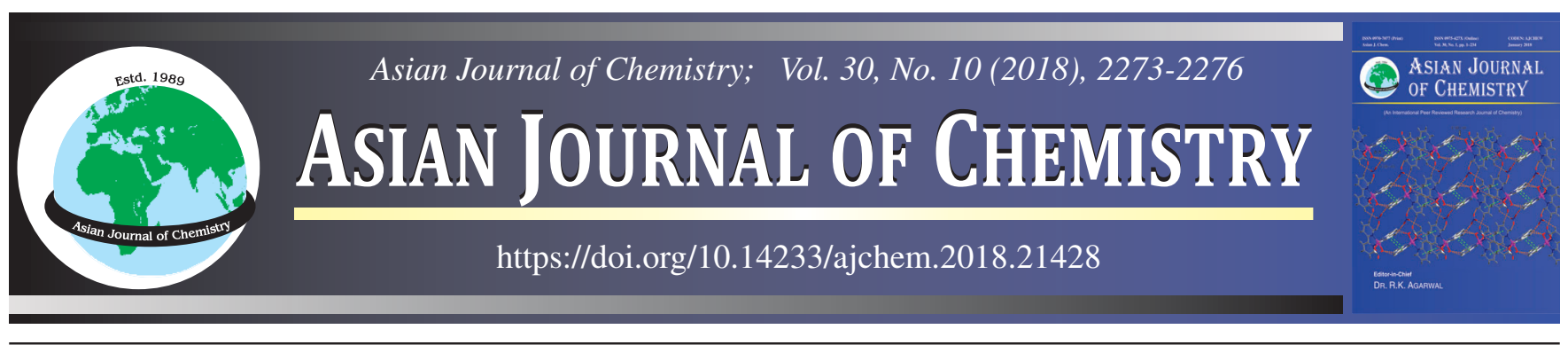

\title{
Selective Cytotoxic Activity of Methyl-3,4,5-trihydroxybenzoate Isolated from Kernel of Bambangan (Mangifera pajang)
}

\section{A. Che Rahim ${ }^{1}$, M.F. Abu Bakar ${ }^{1, *}$, N.K. Kassim ${ }^{2}$, J. Stanslas $^{3}$ and W.N.I. Wan Mohamad Zain ${ }^{4}$}

${ }^{1}$ Department of Technology and Natural Resources, Faculty of Applied Sciences and Technology, Universiti Tun Hussein Onn, Malaysia, Pagoh Campus, KM1 Panchor Road, 84000 Muar, Johor, Malaysia

${ }^{2}$ Department of Chemistry, Faculty of Science, Universiti Putra Malaysia, 43400 UPM, Serdang, Selangor, Malaysia

${ }^{3}$ Department of Medicine, Faculty of Medicine and Health Sciences, Universiti Putra Malaysia, 43400 UPM, Serdang, Selangor, Malaysia ${ }^{4}$ Department of Biochemistry and Molecular Medicine, Faculty of Medicine, Universiti Teknologi MARA (UiTM) Sungai Buloh Campus, 47000, Sungai Buloh, Selangor, Malaysia

*Corresponding author: Fax: +60 6 9742191; Tel: +60 6 9742021; E-mail: fadzelly@uthm.edu.my

Bambangan (Mangifera pajang) has been shown to exhibit anticancer activity. One of the major bioactive compounds present in the methanol extract of kernel of $M$. pajang is methyl 3,4,5-trihydroxybenzoate (methyl gallate). The present study was conducted to evaluate the cytotoxic activity of this compound against selected cancer cell lines such as hormone dependent breast cancer (MCF-7), nonhormone dependent breast cancer (MDA-MB-231), prostate cancer (PC-3), pancreatic cancer cell (CP-2) and colon cancer (HCT-116) cell lines. Methyl gallate was isolated from methanol extract by using column chromatography and the compound was further confirmed by using NMR, GC-MS analysis and comparison of spectral data of the isolated data with published report. The cytotoxicity of the compound was evaluated using 3-(4,5-dimethylthiazol-2-yl)-2,5-diphenyl tetrazolium bromide (MTT) assay at concentrationsranging from 0 to $100 \mu \mathrm{M}$. The results showed that the compound only induced cytotoxicity in MCF-7 and PC-3 cell lines with IC $\mathrm{C}_{50}$ values of 54.7 \pm 4.73 and $97.6 \pm 4.04 \mu \mathrm{M}$, respectively. Furthermore, Capan 2, MDA-MB-231 and HCT-116 showed no inhibition towards the cell proliferation after the treatment with compound $\left(\mathrm{IC}_{50}\right.$ values more than $\left.100 \mu \mathrm{M}\right)$. Thus, the compound isolated from kernel of $M$. pajang exhibited selective cytotoxic activity against selected cancer cell lines.

Keywords: Methyl gallate, Mangifera pajang, Cytotoxicity, MTT assay, Cancer cells.

\section{INTRODUCTION}

Cancer is a general term that used to describe a group of diseases that can affect any parts of the body. It has been found to be the fourth leading cause of death in Malaysia. Cancer can be developed by many factors such as radiation, tobacco and exposure to chemicals. Not only that some internal factors may be the cause to cancer to be worsen such as hormone imbalance, inherited mutation and immune system [1]. To date, in order to combat cancer there are several significant treatments that are available by surgery, chemotherapy and radiotherapy [2]. However, drugs that been used in chemotherapy (such as doxorubicin and cisplatin) were found to be high in toxicity and can induce side effect both on tumorous and normal cell as well [3]. Thus, it is clear that the investigation of plant derived anticancer compound giving the opportunity for the development of anticancer drugs from the natural resources, which have long being used traditionally to treat many diseases.

Mangifera pajang, also known as Bambangan is a species of mango group which widely can be found in Borneo Island of Malaysia (Sabah-Sarawak), Indonesia (Kalimantan) and Brunei [4]. The natives of Island have practically consuming fruit of this plant as their staple food by making the flesh as pickle. Not only that the grated kernel that have been fermented for several days are added and eaten with rice [5]. A review by Abu Bakar and Fry [6] reported that the M. pajang contained diverse phytochemicals and display various promising health benefits. In previous study, it has been reported that kernel extract of this plant consisting high level of phenolic phytochemicals [7] such as caffeic acid, chlorogenic acid, $p$-coumaric acid,

This is an open access journal, and articles are distributed under the terms of the Creative Commons Attribution-NonCommercial 4.0 International (CC BY-NC 4.0) License, which allows others to copy and redistribute the material in any medium or format, remix, transform, and build upon the material, as long as appropriate credit is given and the new creations are licensed under the identical terms. 
gallic acid and sinapic acid as well as flavonoids groups such as diosmin, hesperidin, naringin and rutin [8]. A related study also reported that only the kernel and peel extracts exhibit cytotoxic effects on proliferation of liver and ovarian cancer cell lines with an $\mathrm{IC}_{50}$ value ranging from $35-92 \mu \mathrm{g} / \mathrm{mL}$ [8]. Different fruit parts of $M$. pajang such as peel, pulp and kernel displayed antioxidant [7], antibacterial and anticancer activities $[6,7]$.

There are many studies on the plant extract and isolated compounds been tested in vitro and in vivo for the cytotoxicity purposes by using different human cell lines including liver colon, prostate and breast cancer cell lines. The evaluation of cytotoxicity of plant extract and isolated compounds are crucial as they bring effect to the drug discovery [9]. Literature search have revealed numbers of compounds previously have been isolated from this plant species but not with the anticancer activity from $M$. pajang. Herein, this study part was aimed in anticancer activity of methanol and ethyl acetate extract. Moreover, lead compound belong to phenolic acid was isolated from the active extract and its anticancer properties towards proliferation of selected cancer cell lines was determined.

\section{EXPERIMENTAL}

Extraction and isolation: Plant materials were collected from Penampang, Sabah, Malaysia and identification was done by Dr. Mohd Fadzelly Abu Bakar from Universiti Tun Hussein Onn Malaysia (UTHM). Plant kernel of M. pajang were separated from its flesh and peel before dried and ground into powder $(800 \mathrm{~g})$. Isolation of bioactive compound was conducted using method of Ahmad et al. [4].

Cell culture: All cells used were obtained from ATCC and maintained in RPMI 1640. Meanwhile, Capan 2 carcinoma cell was maintained in McCoy's 5a supplemented with $10 \%$ fetal bovine serum, $1 \%$ penicillin-streptomycin at $37^{\circ} \mathrm{C}$ in $5 \% \mathrm{CO}_{2}$ incubated in a humidified incubator [10]. The cultures were closely monitored under inverted microscope until the cell reached $80 \%$ confluence. Adherent cancer cells approaching $80 \%$ confluency were harvested by washing with phosphate buffer saline and followed by trypsin to detach the cell from the culture flask. The harvested cells were then collected in a fresh medium and sub-cultured at densities of 1.0-5.0 $\times 10^{5}$ cells/ $\mathrm{mL}$ into $25 \mathrm{~cm}^{2}$ flask as being adopted by Stanslas [11].

Cytotoxicity activity using MTT assay: The log phase cells with viability of $80 \%$ were trypsinized to detach the cells from the culture flask. Cells were then collected in a fresh medium and the number of the cells were determined. About 2000 cells in $180 \mu \mathrm{L}$ of medium were seeded into each well of 96 well plate and incubated for $24 \mathrm{~h}$ before the drug was introduced. The stock solution of $10^{5} \mu \mathrm{g} \mathrm{mL}^{-1}$ were prepared by using dimethyl sulphoxide of concentration ranging from $1000 \mu \mathrm{g} \mathrm{mL}^{-1}$ to $1 \mu \mathrm{g} \mathrm{mL} L^{-1}$. Working solution were prepared by 10 times dilution of stock and $20 \mu \mathrm{L}$ of these concentrations was added into each well yield a final concentration ranging from $(100 \mu \mathrm{g}$ $\mathrm{mL}^{-1}$ to $0.1 \mu \mathrm{g} \mathrm{mL}^{-1}$ ). The final mixture used for treating the cell contained not more than $0.1 \%$ of the solvent, the same as for the control wells. The plates were then incubated at $5 \% \mathrm{CO}_{2}$, $37^{\circ} \mathrm{C}$ under high humidity for 4 days and the viability of cells in the plates were determined. $50 \mu \mathrm{L}$ of MTT solution $(5 \mathrm{mg}$
$\mathrm{mL}^{-1}$ ) were added into each well and incubated for another $4 \mathrm{~h}$. The medium was aspirated and crystal formazan precipitate was dissolved in DMSO. The plate was then analyzed using SOFTProMax spectrophotometer. All experiments were performed in triplicates. The $\mathrm{IC}_{50}$ was generated from graph of cell viability against concentrations of compound.

\section{RESULTS AND DISCUSSION}

Isolation of compound: By referring the isolation method of Ahmad et al. [4] with slight modification, pure compound of methyl gallate $(20.3 \mathrm{mg})$ was isolated from methanolic extract of kernel of $M$. pajang by using column chromatography (unpublished report). The spectroscopic data of isolated compound was analyzed by using nuclear magnetic resonance (NMR), gas-chromatography mass spectrometer (GC-MS) analysis and direct comparison of spectral data of isolated compound with the published report of Daud et al. [14]. The isolated compound was identified to be methyl-3,4,5-trihydroxybenzoate (methyl gallate). This compound has been widely reported to be the major components in the Mangifera species and displayed the best cytotoxicity activity due to carbonyl and three hydroxyl groups which attached to benzene ring [4]. Phenolic compounds (caffeic acid, chlorogenic acid, $p$-coumaric acid, ferulic acid, gallic acid and sinapic acid) and flavonoids (diosmin, hesperidin, naringin and sinapic acid) have also been reported to be the major groups of phytochemicals in M. pajang kernel [12].

The isolation of compound from the present study has provided an additional support for the previous study of Ahmad et al. [4], where isolation of identical compound from the same active extract were reported. This compound also been reported to occur in ethanolic extract of Galla rhois [13], Labisa pumila Benth. [14] and known to have antimicrobial properties [4] and strong antioxidant properties [15].

Cytotoxic potential: The cell viability was analyzed by using MTT assay originally described by Mosmann [16], has been used to define quantitative colorimetric assay for cell survival and proliferation based on reduction of tetrazolium salt to purple insoluble formazan. These cell lines were tested with crude extract at the highest concentration of $100 \mu \mathrm{g} / \mathrm{mL}$. Based on the dose response curve, polar solvents (ethyl acetate and methanol extracts) shown good cytotoxicity on MCF-7, HCT116, PC3 and Capan 2 (Table-1). This may be due to the presence of cytotoxic methyl gallate constituents. Meanwhile, hexane and chloroform extracts were considered no cytotoxicity towards the cancerous cell lines, which exhibited $\mathrm{IC}_{50}$ values greater than $100 \mu \mathrm{g} / \mathrm{mL}$. In comparison with the present study, one of the active extracts (ethyl acetate: $21 \mu \mathrm{g} / \mathrm{mL}$ ) was much lower compared to $\mathrm{IC}_{50}$ value of ethanolic extract from the previous study of Abu Bakar et al. [8] when treated towards the same cancer cell line (MCF-7). Moreover, different solvent used in the extraction method may influence the types of compounds that may present in the plant extract. In agreement with this study, the same trend of cytotoxicity was also reported by Ahmad et al. [4] which the cytotoxicity of both extracts were less than $10 \mu \mathrm{g} / \mathrm{mL}$ against MCF-7, HeLa and HT29 cell lines.

From the isolated compound, only MCF-7 and PC-3 were inhibited by methyl gallate at the highest concentration tested $(100 \mu \mathrm{M})$. The results (Table-2) obtained indicated that the 


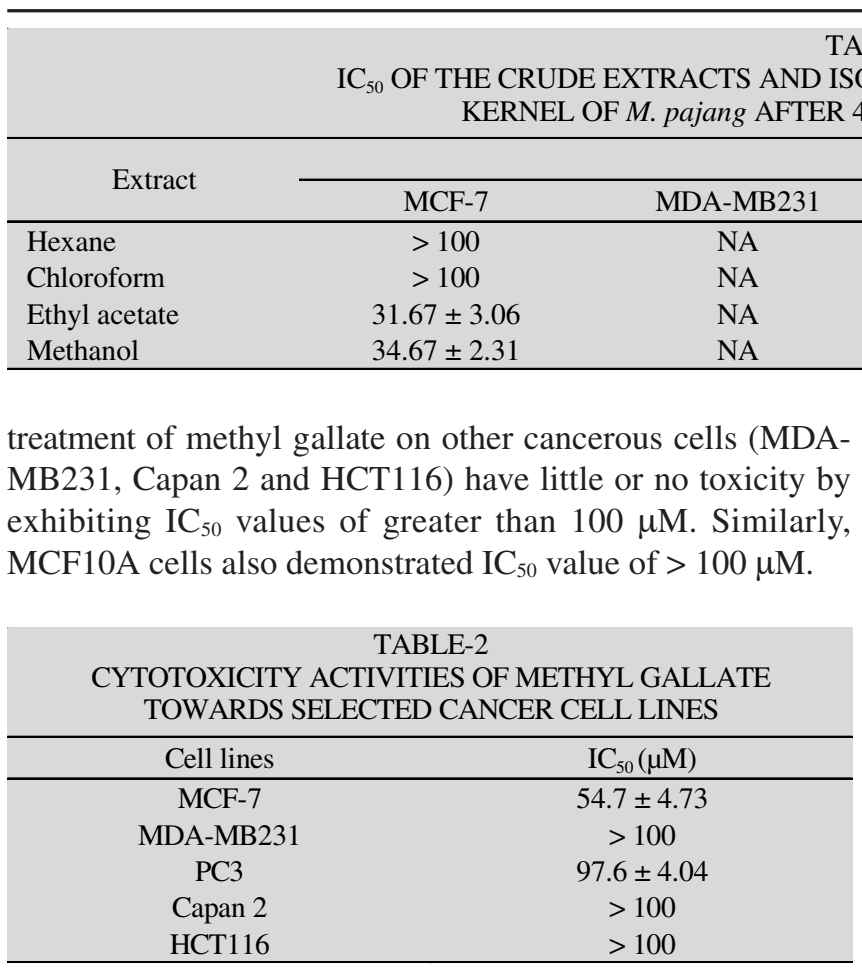

As shown in Table-2, methyl gallate exhibited the lowest $\mathrm{IC}_{50}$ value in MCF-7 $(54.7 \pm 4.73 \mu \mathrm{M})$ indicating that it marked cytotoxic effects on hormone dependent breast cancer cell. The less cytotoxic effects of methyl gallate was exhibited in prostate cancer cell with $\mathrm{IC}_{50}$ value $97.6 \pm 4.04 \mu \mathrm{M}$. This finding is consistent with the observation of Ahmad et al. [4] which reported that there are inhibition of cell growth of MCF-7 and colon cancer cell at the concentration of lower than $20 \mu \mathrm{g} / \mathrm{mL}$ by similar compound. Methyl gallate have also been isolated from the seed kernel of Mangifera indica Linn. cultivar ChokAnnan as the main phenolic acid and flavonoid and exhibit potent antioxidant properties [17]. Besides, it was reported that methyl gallate is an excellent antioxidant and inhibit lipid oxidation [18]. Not only that methyl gallate also reported to exhibit good anti-bacterial properties by inhibiting the growth of intestinal bacterial such as Closridium perfringens, Esherichia coli and Salmonella typhimurium [19].

In addition to anticancer activity of methyl gallate, further investigation on the antioxidant of this bioactive compound also being conducted in the previous study, where it showed the strong scavenging activity with an $\mathrm{IC}_{50}$ value of $2.8 \mu \mathrm{g} / \mathrm{mL}$ [20]. The activity of isolated compound probably has a strong structure-activity relationship as suggested by Fiuza et al. [21]. In conjunction with the recent study, this assay is important to define the basal cytotoxicity of this compound towards the cancerous cell activity such as intrinsic ability of this compound to cause cell death as a result of damage to several cellular functions. The assay was evaluated based on the intensity of purple formazan crystal, which is a reduced-form of water soluble tetrazolium salt (MTT) [22-25] measured directly to proportional to the number of viable cells in the culture [26-28]. This preliminary data also important to define the concentration range for more details in vitro study to provide information on the molecular mechanisms underlying that may contributed to anticancer role of methyl gallate [29].
TABLE-1

ISOLATED COMPOUND FROM EXTRACTS OF ONEVERAL CELLLINES

\section{$\mathrm{IC}_{50}(\mu \mathrm{g} / \mathrm{mL})$}

$\begin{array}{ccc}\text { PC3 } & \text { Capan } 2 & \text { HCT116 } \\ >100 & >100 & >100 \\ >100 & >100 & >100 \\ 31.67 \pm 3.51 & 17.67 \pm 4.73 & 41.33 \pm 2.08 \\ 30.0 \pm 2.0 & 54.33 \pm 9.01 & 34.44 \pm 2.08\end{array}$

The community of Kadazan-Dusun people in Sabah, Malaysia has developed variety of traditional cruisine using fresh and preserved fruits of Bambangan (M. pajang). Several studies on phytochemicals and pharmacological properties of this fruit had affirmed that regular consumption of Bambangan fruits among Kadazan-Dusun people would give various health benefits. Functional food products from Bambangan fruits also being developed in Sabah, Malaysia. Not only that, present study could serve as preliminary data towards developing of pharmaceutical applications of the by-products (kernel), which are abundant in supply following consumption of edible parts of fruits.

\section{Conclusion}

In conclusion, screening of cytotoxicity of the crude extracts revealed that the methanolic and ethyl acetate extract exhibited significant anticancer activity against MCF-7, HCT116- Capan 2 and PC 3 cell lines. This can also be the evidence for the presence of effective anticancer agent, which have been isolated and identified as methyl gallate might be contributing to the anticancer property. Despite the selective cytotoxicity displayed by the active compound, further research is needed to be conducted as methyl gallate may be useful in breast cancer treatment and prevention.

\section{ACKNOWLEDGEMENTS}

This study was funded by Ministry of Higher education of Malaysia (MoHE) under Fundamental Research Grant Scheme (Vot: 1560) as well as UTHM Contract Grant for publication (U555). Special thanks to Universiti Tun Hussein Onn Malaysia (UTHM), Universiti Putra Malaysia (UPM) and Universiti Teknologi MARA (UiTM) for the use of laboratories and technical assistance.

\section{CONFLICT OF INTEREST}

The authors declare that there is no conflict of interests regarding the publication of this article.

\section{REFERENCES}

1. J.A.J. Sunilson, G. Rejitha, K. Anandarajagopal, A. Das, M. Muthappan and P. Promwichit, Int. J. Cancer Res., 3, 115 (2009)

https://doi.org/10.3923/ijcr.2009.115.122.

2. R. Chang, L. Sun and T.J. Webster, Int. J. Nanomedicine, 9, 461 (2014); https://doi.org/10.2147/IJN.S55505

3. A. McTiernan, R.C. Jinks, M.R. Sydes, B. Uscinska, J.M. Hook, M. van Glabbeke, V. Bramwell, I.J. Lewis, A.H.M. Taminiau, M.A. Nooij, P.C.W. Hogendoorn, H. Gelderblom and J.S. Whelan, Eur. J. Cancer, 48, 703 (2012); https://doi.org/10.1016/j.ejca.2011.09.012.

4. S. Ahmad, M.A. Sukari, N. Ismail, I.S. Ismail, A.B. Abdul, M.F. Abu Bakar, N. Kifli and G.C.L. Ee, BMC Complement. Altern. Med., 15, 83 (2015); https://doi.org/10.1186/s12906-015-0594-7. 
5. J. Tangah, F.E. Bajau, W. Jilimin, H.T. Chan, S.K. Wong and E.W.C. Chan, Syst. Rev. Pharm., 8, 86 (2017); https://doi.org/10.5530/srp.2017.1.15.

6. M.F. Abu Bakar and J. Fry, J. Med. Plants Res., 45, 3292 (2013); https://doi.org/10.5897/JMPR2013.5299.

7. M.F. Abu Bakar, M. Mohamed, A. Rahmat and J.R. Fry, Food Chem., 113, 479 (2009); https://doi.org/10.1016/j.foodchem.2008.07.081.

8. M.F. Abu Bakar, M. Mohamad, A. Rahmat, S.A. Burr and J.R. Fry, Food Chem. Toxicol., 48, 1688 (2010a); https://doi.org/10.1016/j.fct.2010.03.046.

9. N. Lall and J.J.M. Meyer, J. Ethnopharmacol., 72, 313 (2000); https://doi.org/10.1016/S0378-8741(00)00231-2.

10. M.A.R.K. Greeve and J.M. Allan, J. Mol. Endocrinol., 32, 793 (2004); https://doi.org/10.1677/jme. 0.0320793 .

11. J. Stanslas, Ph.D. Thesis, Mechanisms of Antitumor Activities of Novel Polycyclic Acridines, University of Nottingham, UK (1998).

12. M. Fadzelly Abu Bakar, M. Mohamed, A. Rahmat, S.A. Burr and J.R. Fry, Nutr. Food Sci., 1, 29 (2010b); https://doi.org/10.1108/00346651011015890.

13. J.-G. Choi, S.-H. Mun, H.S. Chahar, P. Bharaj, O.-H. Kang, S.-G. Kim, D.-W. Shin and D.-Y. Kwon, PLoS One, 9, e102697 (2014); https://doi.org/10.1371/journal.pone.0102697.

14. M.N.H. Daud, M.L. Jabit, M.N. Jalil, N. Ahamad and N.N. Mohd Feteri, J. Trop. Agric. Fund. Sci., 2, 279 (2011).

15. M.T. Ekaprasada, H. Nurdin, S. Ibrahim and H. Dachriyanus, Indo. J. Chem., 3, 457 (2009).

16. T. Mosmann, J. Immunol. Methods, 65, 55 (1983); https://doi.org/10.1016/0022-1759(83)90303-4.

17. P. Maisuthisakul and M.H. Gordon, J. Food Sci. Technol., 51, 1453 (2014); https://doi.org/10.1007/s13197-011-0604-9.

18. Q. Chen, K. Song, L. Qiu, X. Liu, H. Huang and H. Guo, Food Chem., 91, 269 (2005); https://doi.org/10.1016/j.foodchem.2004.01.078.
19. G. Saxena, A.R. McCutcheon, S. Farmer, G.H. Towers and R.E. Hancock, J. Ethnopharmacol., 42, 95 (1994); https://doi.org/10.1016/0378-8741(94)90102-3.

20. Y.H. Choy, S.S. Han, H.O. Lee and S.H. Baek, Bull. Korean Chem. Soc., 26, 1450 (2005); https://doi.org/10.5012/bkcs.2005.26.9.1450.

21. S.M. Fiuza, C. Gomes, L.J. Teixeira, M.T.G. da Cruz, M.N.D.S. Cordeiro, N. Milhazes, F. Borges and M.P.M. Marques, Bioorg. Med. Chem., 12, 3581 (2004); https://doi.org/10.1016/j.bmc.2004.04.026.

22. H. Garn, H. Krause, V. Enzmann and K. Dröâler, J. Immunol. Methods, 168, 253 (1994); https://doi.org/10.1016/0022-1759(94)90062-0.

23. S.M. Thom, R.W. Horobin, E. Seidler and M.R. Barer, J. Appl. Bacteriol., 74, 433 (1993); https://doi.org/10.1111/j.1365-2672.1993.tb05151.x.

24. M. Shoemaker, I. Cohen and M. Campbell, J. Ethnopharmacol., 93, 381 (2004); https://doi.org/10.1016/j.jep.2004.04.011.

25. L. Peng, B. Wang and P. Ren, Biointerfaces, 45, 108 (2005); https://doi.org/10.1016/j.colsurfb.2005.07.014.

26. S.R. Kim, M.J. Park, M.K. Lee, S.H. Sung, E.J. Park, J. Kim, S.Y. Kim, T.H. Oh, G.J. Markelonis and Y.C. Kim, Free Radic. Biol. Med., 32, 596 (2002); https://doi.org/10.1016/S0891-5849(02)00751-7.

27. S.H. Kim, J.H. Zo, M.A. Kim, K.K. Hwang, I.H. Chae, H.-S. Kim, C.H. Kim, D.-W. Sohn, B.-H. Oh, M.-M. Lee and Y.-B. Park, Nutr. Res., 23, 1671 (2003); https://doi.org/10.1016/j.nutres.2003.08.001.

28. H.Y. Lin, S.H. Juan, S.C. Shen, F.L. Hsu and Y.C. Chen, Biochem. Pharmacol., 66, 1821 (2003); https://doi.org/10.1016/S0006-2952(03)00422-2.

29. C. Bouaziz, S. Abid-Essefi, A. Bouslimi, E. El Golli and H. Bacha, Toxicon, 48, 343 (2006); https://doi.org/10.1016/j.toxicon.2006.06.004. 